\title{
Fostering innovation at University of Debrecen
}

\section{Péter Popovics ${ }^{1}$, Lilla Jutkusz ${ }^{2}$, Károly Pető ${ }^{3}$, Zoltán Szakály ${ }^{4}$, Zoltán Bács ${ }^{5}$}

${ }^{1}$ Institute of Applied Economics Sciences, University of Debrecen, Hungary, ${ }^{2}$ Chancellery, University of Debrecen, Hungary, ${ }^{3}$ Institute of Rural Development, Tourism and Sports Management, University of Debrecen, Hungary, ${ }^{4}$ Institute of Marketing and Trade, University of Debrecen, Hungary, ${ }^{5}$ Institute of Accounting and Finance, University of Debrecen, Hungary.

\begin{abstract}
The aim of our writing is to present the opportunities offered by the University of Debrecen to students and researchers for the further development of innovative ideas in the marketplace, and to identify the essential linking elements of the university's innovative environment that can have an impact based on mutual benefits from local, regional, national and international levels.

The University of Debrecen's Innovation Ecosystem Center (IEC) is an organization that is constantly evolving to meet the needs of the university in terms of innovation, development of corporate cooperation and technology transfer. It aims to promote industrial exploitation of research results and promote the introduction of ideas into the market. It is one of the tasks of the IEC - in line with what was said at the World Economic Forum in 2018 - to spread the entrepreneurial mindset, to strengthen corporate relations and to take a positive social impact approach to innovation processes.

To help the University of Debrecen to fully fulfil its mission of innovation and its visibility and recognition from the local to the international level, thereby contributing to the wider (market) exploitation of university ideas, and contributing to the cooperation between the competitive and governmental sectors. For the development of the local economy and for addressing environmental-socio-economic challenges, it is essential to provide a professional environment in an incubation center that meets the demands of the 21 st century
\end{abstract}

Keywords: Innovation; Entrepreneurship; Incubation; Innovation Centre; Start-up ecosystem. 


\section{Introduction}

Higher education is facing significant changes worldwide, leading to the emergence of new institutional models of operation in recent decades. Besides the aspects of sustainable funding, there are several triggering factors for adjusting the provision of educational, research and other services to changing conditions and market needs: accelerating change in science and technology, increased competition for innovation, globalization and internationalization, the emerging need for practice-oriented training and the widespread lifelong learning (Barakonyi, 2014).

To provide quality services, diversification of funding has become inevitable. In addition to the budgetary resources provided as normative support based on the number of students, typically higher education institutions have access to additional government and community budgetary resources through tenders for institutional development and research activities. Intensifying relations with external (economic) actors is a new opportunity that may contribute both to the expansion of available financial resources and to the harmonization of higher education services with market expectations. External actors as collaborating partners, costumers of educational and R\&D services or entities exploiting the R\&D results achieved through technology transfer can provide additional financial (and human) resources and expertise to higher education institutions.

In addition to funding issues, the strengthening the role of higher education institutions in $\mathrm{R} \& \mathrm{D}$ and its contribution to local economic development and society is strongly reflected in EU and national strategic goals. In Hungary, the government strategy also explicitly identifies higher education institutions as the "most important scientific, professional and organizational actors in domestic R\&D\&I": with regard to the third mission activities, "strengthening the impact of higher education in local economic development" and within this framework, creating favourable conditions to innovation (strengthening technology transfer, incubation and other related services), reinforcing social innovation and strengthening the service function will be of priority (Magyar Közlöny (2013), Stratégia (2016), Stratégia (2017)).

Depending on operational frameworks, industry relations and experience in innovation management, European higher education institutions will pursue different strategies and provide different services as third mission activities are concerned. There are several higher education institutions offering profit oriented services: operating incubators, innovation and research centers or participating in clusters (Deés, Sz. (2011)). 


\section{Innovation activities at the University of Debrecen}

The University of Debrecen has been striving to respond appropriately to emerging challenges and make the most out of the opportunities arising from the changes in its operating environment since 2005 in many areas, including exploitation of the university's R\&D results, encouraging university citizens to implement their innovative ideas, strengthening educational and research links with economic actors; and offering educational, cultural and sporting programs to local, regional communities.

The technology and knowledge transfer activities have a history of more than a decade: the legal predecessor of the Research Exploitation and Technology Transfer Center (hereinafter referred to as technology transfer office, TTO) was established in 2006 and since 2008 this unit has been responsible for utilizing the research results created at the University. Other key activities of the TTO include intellectual property protection consulting, managing the university's intellectual property portfolio, licensing marketable technologies, supporting other forms of exploitation, and preparing and negotiating the University's R\&D service agreements with partners.

In 2018, the TTO portfolio was extended to the implementation of the Proof of Concept program (see: Figure 1.), funded from own institutional revenues, to promote the exploitation of R\&D results. Building on international experience, the program provides resources to increase the level of technology development of early-stage, university-related ideas and inventions and to support the commercialization of university-generated technologies (gap funding). The aim of the program is to accelerate the exploration of the utilization potential of the research results generated at the University of Debrecen, the setting a utilization roadmap and defining the utilization process in order to reach new milestones in product or service development and testing. It also contributes to reducing the risk of introducing the innovative technology or product and thus making university technologies more attractive to market players. In addition to examining the technological / physical feasibility, mentoring and support activity includes - where appropriate - the examination of marketability and commercial feasibility and the identification of opportunities to engage in follow-on funding (POC, 2018). The researchers involved in the program will receive ongoing technical support both on the innovation process from TTO and on the aspects of marketability and necessary modification to enter the market from industry experts.

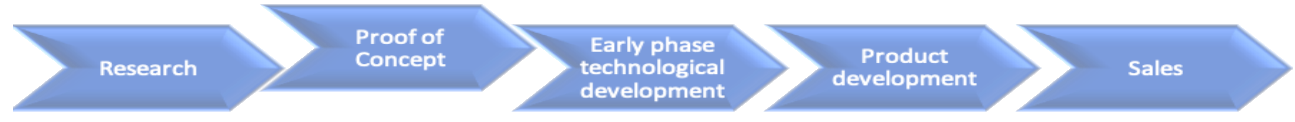

Figure 1. A "Proof of concept"in the innovation process. Source:POC (2018). 
In order to explore and further develop the ideas, a specific call for proposals will be opened for students and young researchers in 2020 within the framework of the POC program, and students will also be able to develop their innovation ideas in a so-called fablabs. In these open labs, students will access tools for design, modelling, electronics at the core facilities or divisions of the university (such as a 3D printer, food innovation lab, electrical engineering lab, etc.). Students will also be offered professional support from the university department's researchers and technical staff in order to deepen their professional and R\&D management knowledge and gain access to international knowledge base.

The fab-lab is based on the free flow and sharing of ideas and provides opportunities for students to join multidisciplinary teams. Fab-labs can make a significant contribution to evolving innovation ecosystem for students and young researchers and increasing the number of start-ups.

The complexity of the programs starting in 2020 is completed with a scholarship program that promotes the discovery of students' innovative ideas at the university and supports the validation, development and prototyping of ideas, being combined with a training program for developing entrepreneurial competencies of talented students and innovative entrepreneurs.

The promotion of the entrepreneurial mindset and the implementation of activities aimed at developing related competences have also been part of the university's training portfolio for nearly a decade. On the one hand, the TTO provides students with detailed information on the innovation process, and on the other hand, specific, credit-based training courses of entrepreneurship are available to students.

Team Academy Debrecen was launched in 2010. The mission of the program is to provide business training that develops entrepreneurial mindsets and self-awareness through practice-oriented and innovative approaches to the requirements of the modern age, creating opportunities for individual fulfilment, responsibility for themselves and the community. Students start a business venture when they begin their studies, and in the course of their studies acquire the related knowledge and develop the competencies needed to run a business in an efficient manner. In addition to first-hand knowledge of the realworld market environment, students will learn how to collaborate in a team, learn to motivate and appreciate themselves and teammates, and to immerse themselves in life -long learning in their own business interests. The students' work is supervised by university professionals (team coaches) who were trained by the Finnish Team Mastery.

This modern teaching methodology is accepted in the field of international business education: Spain, France, Netherlands, England have launched their own "Team Academy" training based on the Finnish model. 
The first courses of the Institute for Innovation in Engineering and Business Development (MÜZLI) established in 2018, were launched in the second semester of the academic year 2018/19. The market-oriented, practice-oriented training brings excellence in domestic and international business to the students of engineering, economics, management and IT.

Corporate professionals with decades of managerial and extensive professional experience ensure that students enter the labour market so that their knowledge, skills and competencies beyond professional knowledge are reinforced, they are able to identify the challenges to be addressed in the new technological era, and are capable of exploring their inherent creativity. The courses are primarily aimed at developing an entrepreneurial mindset but also provide insights into useful experiences gained through personal careers across a range of topics (e.g. benefits of determination or taking risks, key elements of industrial success in the industry, etc.).

In order to coordinate innovation management activities and provide competitive up-to-date services, a decision was made in 2019 to further develop the innovation ecosystem by necessary institutional changes: in line with the University of Debrecen's comprehensive mission statement the Innovation Ecosystem Center (Center) as a service unit, incorporating the Research Exploitation and Technology Transfer Center was established. The Center aims at the effective discovery of ideas, promoting the further development of ideas, the (market) exploitation of research potential and more efficient contribution to the local economic development through cooperation with the business and government sector and promoting the development and implementation of innovative responses to environmental, socio-economic challenges at the local level (IÖK, 2019).

At this point, it is worthwhile to mention the financing aspects of developing an innovation ecosystem and providing services at the early-stage. In addition to government funding sources through tenders, the Innovation Fund of the University of Debrecen (IFUD) was created - which clearly shows the leadership's commitment to promoting innovation. The IFUD provides funding to develop the innovation system, to increase the efficiency and effectiveness of innovation and R\&D activities, and to contribute to the development and market introduction of useful products and services, taking into account social and environmental impacts (DEINA, 2018).

In particular, IFUD may provide funding for:

- the exploitation of R\&D results ("proof of concept" sub-program)

- $\quad$ programs for exploring student ideas, developing and developing entrepreneurial skills (student sub-program)

- the development of the innovation ecosystem and the provision of services, in particular for the basic operation of the Innovation Ecosystem Center and UD Ventures Ltd. (Innovation ecosystem sub-program) 
The aim of the Center, in close cooperation with the relevant departments of the University of Debrecen, is to strengthen entrepreneurial spirit and initiatives, dedication to teamwork and the emergence of ideas, regardless of the uncertainty inherent in innovation. Innovation services, cooperations, collaborations and partnerships reduce the risks behind an innovative idea in the marketplace, and are intended to help idea creators overcome the challenges successfully and effectively or even in the case of market failure of a certain idea encourage to invest energies in a faithful restart of ideation.

The knowledge and competency map on the one hand reveals exploitable R\&D results and on the other hand facilitates to channel researchers and research groups through their available scientific and technological knowledge into new research programs based on domestic or international, research or industrial collaborations. Mentoring of student and research teams, and at a later stage of university-affiliated start-ups, spin-offs and microbusinesses, is based on international best practice. The system may work with mentors volunteering (not generating income, providing only reimbursement of expenses) so that to avoid the conflict of interest and appearance of self-interest.

The Center places particular emphasis on increasing the entrepreneurial activity of students and young researchers and organizes events to promote innovation and entrepreneurship (e.g. conferences, business incubation clubs, pitch competitions). At the same time, the Center - in cooperation with the departments concerned - promotes cooperation between students and the business sector based on international best practice. At some events, student groups design solutions for real industry innovation challenges in a team (development team) supported by facilitators and academic researchers. The Center will start a close cooperation with the clusters operating with active participation and leadership of the University of Debrecen.

\section{Clusters}

The universities play an important role in the knowledge-based economy: they generate knowledge through their leading-edge research activities and provide highly qualified labour. In the case these functions are integrally linked and when they are most effective, the university contributes strongly to regional economic growth and development. It is important to define the precise role they play. Besides being the sources for knowledge and talents, they can also draw the attention of investors and strategically important companies (Wolfe, 2015).

The University of Debrecen is a pioneer in cluster organization in Hungary and plays a key role in creating and operating clusters. The aim of the clusters is to make technology transfer activities more efficient and thus contribute to the economic development of the region. 
Over the past decade, five accredited clusters have been organized around the University of Debrecen, two of which are internationally accredited. Areas of operation of the clusters, in line with the strategic areas designated by the University of Debrecen: pharmaceutical, thermal and tourism, food, sports, information technology, instrument development.

The following clusters are functioning in the neighbourhood of the University of Debrecen:

- Pharmapolis Debrecen Innovative Pharmaceutical Cluster

- Hungarian Sports and Lifestyle Development Cluster

- Northern Great Plain Thermal Cluster

- Pharmapolis Innovative Food Cluster

- $\quad$ Silicon Field Cluster

Through these clusters, the University cooperates closely with hundreds of market players who can serve as a platform for the practical training of students, and effectively serve the utilization of research results and the development of innovation processes in the region.

The uniquely progressive feature of the clusters around the University of Debrecen is that it has created a nation-wide network of capital-intensive medium and large-scale companies, innovative university spin-offs and start-ups, municipalities, financial institutions, chambers. The clusters support the university industrial development efforts of the University.

\section{The Incubation Center}

Incubators are growing worldwide having similar infrastructure and graduation policies, while differing in their selection strategies, business support services and mediation offering (Bergek, A.-Norrman, C. (2008), Hausberg, J.P. - Korreck, S. (2018)).

Depending on operational frameworks, industry relations and experience in innovation management, European higher education institutions will pursue different strategies and provide different services as third mission activities are concerned.

The erection of the Incubation Center is another milestone in the innovation ecosystem development of the University of Debrecen, bringing a new approach to reinforce and extend innovation activities, join the international competition and cooperation between universities and to address local and regional market need more efficiently. The Incubation Center provides a comfortable, modern and healthy site, environment and community culture for the collaboration of educational and research institutions and businesses that attracts investment in research and thus contributes to economic growth.

The objective to be achieved through the establishment of the Incubation Center - in line with the university's innovation and business objectives - is to provide the appropriate site 
to carry out incubation, acceleration, business development and related mentoring and advisory activities and project management tasks. The services of the co-working space will primarily be available for the researchers and students of the University of Debrecen.

The Incubation Center provides a venue for trainings and other advisory services offered by the Innovation Ecosystem Center that are designed and differentiated to suit the business, strategic, organizational or personal development needs and objectives of innovative teams.

- Within the framework of the Action Learning Group, advisory services, such as facilitation, peer mentoring, performance and process management, exchange of professional experience will be provided, and a focus would be on development of collaboration and knowledge sharing. The following skills and competences will be developed during the training: goal setting, focus, change management, decision making, presentation, feedback, knowledge-mobilising interviewing and summation techniques, constructive confrontation, performance-enhancing reflection at the individual level or within a group, self-reflection - self-awareness, problem-solving potential and innovation.

- Business coaching focuses on developing entrepreneurial skills, innovation and motivation through adequate process management models to achieve higher performance or profitability, and consulting to determine real, achievable and measurable business goals with respect to external and internal available and the deficiency of specific resources and preparation of strategic and implementation plans. Commitment, motivation and entrepreneurial mindset are the added value of the development process.

The process of facilitation and development takes place in a cyclical structure: consultation - implementation - monitoring, feedback, refinement - learning (Kolb, 1984).

- Leadership mentoring, trainings are available as a service to increase efficiency and motivation. The intervention process supports the development of professional identity and the effectiveness of professional role and responsibility, contributes to increased motivation, and promotes talent development and retention. The training covers the areas of delegation and empowerment, decision-making techniques, assertive communication proactive modes of operation, resource management, problem solving and creativity development, change management, performance management, project management.

- In pitch training, students and researchers learn pitching through practice-oriented simulation modules, psychological, communication and presentation exercises. As a result of the activity, participants will be able to communicate effectively with investors and the likelihood of success will increase resulting in higher investments for faster growth.

The spaces created within the Incubation Center provide opportunities for team development and interaction between teams. 
- In innovation open-spaces (co-working office), individuals and teams with an innovation idea can do office work on a hot-desk basis.

- Incubation teams can work in community-based hack-space to develop board models, prototype space, and equipment accessories (from simple machines to $3 \mathrm{D}$ printers).

- Incubation facilities (small and medium-sized offices) for groups, meeting room

In line with the University of Debrecen's goals to creating a broad network of innovationrelated cooperations based on mutual benefit, the Incubation Center will greatly contribute to the development and strengthening of further economically beneficial links between the University of Debrecen and other economic actors. Service labs and R\&D companies hosted at the first level of the Incubation Center, through their market-based services, R\&D activities, and their role in student training, help to strengthen relationships and increase economic embeddedness.

\section{References}

Barakonyi Károly (2014). Felsőoktatásunk 25 éve (eredmények - kudarcok). Felsőoktatási MÜHELY 2007-2014, 2014/II. szám - A rendszerváltó magyar felsőoktatás

Bergek, A. - Norrman, C. (2008). Incubator best practice: A framework. Technovation, 28(1-2), 20-28.

Deés, Sz. (2011). Egyetemi tudománymarketing a harmadik generációs egyetem szemlélete és kommunikációja. Doktori Értekezés, Pécsi Egyetem

Hausberg, J.P. - Korreck, S. (2018). Business incubators and accelerators: a co-citation analysis-based, systematic literature review. The Journal of Technology Transfer pp 1$\underline{26}$

Kolb, D. A. (1984). Experiential learning: Experience as the source of learning and development (Vol. 1). Englewood Cliffs, NJ: Prentice-Hall.

Wolfe, D. A. (2015). The Role of Universities in Regional Development and Cluster Formation. In Glen Alan Jones, Patricia L. McCarney \& Michael L. Skolnik (eds.), Creating Knowledge, Strengthening Nations: The Changing Role of Higher Education. University of Toronto Press. pp. 167--94 (2005)

\section{University internal documents:}

POC (2018). Proof of Concept Program, https://unideb.hu/hu/pocprogram

DEINA (2018). Debreceni Egyetem Innovációs Alap felhasználási és végrehajtási koncepció

IÖK (2019). Debreceni Egyetem Innovációs Ökoszisztéma Központ szakmai koncepció

\section{Strategy documents:}


Stratégia (2016). Fokozatváltás a felsőoktatásban, A teljesitményelvü felsőoktatás fejlesztésének irányvonalai. A Kormány 1785/2016. (XII. 16.) Korm. határozata a „Fokozatváltás a felsőoktatásban középtávú szakpolitikai stratégia 2016” elfogadásáról

Stratégia (2017). Fokozatváltás a felsőoktatásban középtávú szakpolitikai stratégia 20162020 évekre vonatkozó cselekvési tervéröl. A Kormány 1359/2017. (VI. 12.) Korm. határozata

Magyar Közlöny (2013). Befektetés a jövőbe, Nemzeti Kutatás-fejlesztési és Innovációs Stratégia (2013-2020), (Stratégia (2013)), A Kormány 1414/2013. (VII. 4.) Korm. Határozata a Nemzeti Kutatás-fejlesztési és Innovációs Stratégia (2013-2020) elfogadásáról 